\title{
Cytological And Histochemical Studies On Rat Liver And Pancreas During Progression Of Streptozotocin Induced Diabetes And Possible Protection Using Certain Natural Antioxidants
}

\author{
Hanaa F. Waer*, Seham A. Helmy** \\ *Atomic Energy Authority. National Center For Radiation Research and Technology, Biology Department \\ *(King Khaled University Faculty of Science - University Center for Girls) \\ **Suez Canal University, Faculty of Veterinary Medicine, Department of Cytology and Histology.
}

\begin{abstract}
Background: Diabetes mellitus is a major endocrine disorder and growing health problem in most countries. Diabetes manifested by experimental animal models exhibits high oxidative stress due to persistent and chronic hyperglycemia which increases the generation of free radicals, streptozotocin (STZ) provides an animal model of type 1 diabetes. Thereby depleting the activities of antioxidative defense systems with alteration of antioxidant activities of enzymes such as green tea and curcumin .

Aim : Biochemical histological and histochemical investigations were carried on to revel the effect of STZ on the liver and pancreas cells. Natural antioxidants were used as a new way for ameliorating diabetic effect on the cells
\end{abstract}

Material and methods: Diabetes was induced by a single intraperitoneal injection of freshly prepared STZ dissolved in $0.05 \mathrm{M}$ of sodium citrate buffer, $\mathrm{pH}=4.6$, (STZ; $45 \mathrm{mg} / \mathrm{kg} \mathrm{B}$.wt.). Three days after degeneration of beta cells, diabetes was induced in all animals. After induction of diabetes, diabetic and normal animals were kept in metabolic cages separately. Green tea (EGCG) and curcumin are used as natural antioxidants to improve the disorders and structural changes induced by STZ. Cellular and histochemical investigations were carried on the changes induced in the pancreatic and hepatic tissues. Body weight, level of serum glucose and insulin were calculated in the control and treated groups. For detecting the degeneration of both hepatocytes and pancreatic cells of diabetic rats, tissue samples from diabetic and treated rats were collected and pathologically examined.

Results: The present investigations reveled that there was a detectable amelioration on the injures induced by STZ on both hepatocytes and pancreatic cells using green tea or curcumin with a detectable dose level. Also it can be observed that the ameliorated effect induced was a time dependant. Conformation of these results from histochemical detection of polysaccharides and DNA contents were detected by PAS and Feulgen reactions.

Conclusion: Curcumin and green tea look to have a powerful effect against diabetic cell injury induced in both rat liver and pancreas. The ameliorating effect seem to be time dependant.

KEY WORDS: Biochemistry, Liver, Pancreas, Pathology, STZ, histochemistry. 


\section{Introduction:}

Diabetes is a chronic disease that is relatively common throughout the world. In recent decades, various epidemiological studies have been carried out on prevalence of diabetes mellitus all over the world according to which the population of diabetics was obviously increased according to World Health Organization reports, more than 150 million people throughout the world suffered from diabetes while the mankind has been unable to solve this problem, (WHO, 2009).

Administration of $60 \mathrm{mg} / \mathrm{kg}$ Streptozotocin dose can initiate an autoimmune process that results in the destruction of beta cells of Langerhans islets. Ultimately contributing to the toxicity of beta cells. According to this model, oxidative stress is produced under diabetic conditions which possibly cause various forms of tissue damage in patients with diabetes. Diabetes mellitus is a complex and a multifarious group of disorders that disturb the metabolism of carbohydrates, fats and proteins. It results from shortage or lack of insulin secretion or reduced sensitivity of the tissue to insulin. Several drugs such as biguanides and sulfonylureas are currently available to reduce hyperglycemia in diabetes mellitus (Mutalik et al., 2003; Halberstein, 2005). Treatment of diabetes starts with a healthy diet and natural antioxidant. The diet should be low in refined sugars and fats. Diet should be high in fibers, grains and legumes (beans, peas). Nuts, onions and garlic are good for maintaining blood glucose levels coming to this fact. Antioxidants can exert beneficial effects on both liver and pancreatic B-cell function in diabetes (Calabrese, 2003). Thus a sufficient supply of antioxidants may prevent or delay B-cell dysfunction in diabetes by providing protection against glucose toxicity. Green tea has protective effect in assisting diabetics and in particular type 1 diabetics, with the breakdown of blood glucose (Hirosh et al., 2004). Although many plants offer certain medical benefits others were unproven by the scientific researches on animals has suggested that, green tea may in fact help to prevent the development of type 1 diabetes also helping to regulate blood sugar levels in those who already have type 1 diabetes. Type 1 diabetics do not produce insulin which breaks down glucose in the blood, but the use of green tea may help in regulating these blood sugar levels and so be beneficial for diabetics (Hiserodt et al., 2011). Many question related to antioxidant effect of the green tea extract remain unanswered. Much more work is clearly orally administration of green tea extract $(1.5 \%, \mathrm{w} / \mathrm{v})$ produced significantly reduction of blood glucose level in healthy normal rats at the same time it had been found that it had a significant hypoglycemic effect in diabetic rats, (Crespy and Williamson, 2004; Harris, 2005).

At the same level, curcumin found to be the main biologically active photochemical compound of turmeric. It is extracted, concentrated, standardized and researched. Curcumin, which gives the yellow color to turmeric, was first isolated almost two centuries ago, and its structure as diferuloylmethane was determined in 1910 . Curcumin (diferuloylmethane) is a naturally occurring yellow pigment isolated from the rhizomes of the plant Curcuma longa (Linn) found in south 
Asia and is a potent antioxidant agent and free radical scavenger (Lodha and Baggha, 2000; Malee et al., 2010). Extensive research within the last half century has proven that, its renowned range of medicinal properties, once associated with turmeric, are due to curcumin, a polyphenolic compound derived from dietary spice turmeric, possesses diverse pharmacologic effects including anti-inflammatory, antioxidant, anti proliferative and anti-angiogenic activities (Malee et al., 2010). Along with being an inhibitor of lipid peroxidation it is also an inhibitor of nitric oxide synthesis (NOS) over expression and of nuclear factor kappa B activation. Curcumin treatment for 12 weeks can exert beneficial effect in diabetes mellitus, regarding the improvement of pancreatic islets. The islets of Langerhans neogenesis is characterized by increased numbers of small islets (Meghana et al., 2007; Malee et al., 2010). The efficacy of curcumin has been widely observed in reducing various diabetic secondary complications such as diabetic nephropathy/renal lesions retinopathy wound healing and reduction of advanced glycation end products. Further studies evaluated the effect of curcumin that could influence pancreatic islets recuperation after the damage induced by STZ (Pari and Murugan, 2005). It had been found that in the diabetic mice which were induced by STZ, DNA was damaged in Beta-cell and subsequent inhibition of insulin biosynthesis and secretion (Panchatcharam et al., 2006; Kanitkar et al., 2008). Clear evidence of pancreatic islets growth to respond to curcumin treatment in diabetic showed that curcumin might promote hormone or growth factors for pancreatic islets in diabetic mice neogenesis (Sharma el al., 2006; Weber el al., 2006).

\section{Material and Methods:}

\section{Animals and Experimental Design:}

The present study was done on healthy adult albino male rats in the weight range of (150-200 gm), selected from an inbred group housed in specially designed cages and maintained under standard conditions of temperature $\left(23 \pm 1{ }^{\circ} \mathrm{C}\right)$ and humidity of (55$60 \%$ ) with a 12-hour light and 12-hour dark cycle for at least one week before use. Rats were grouped to 4 groups each of 10 rats on the basis of initial weight and kept in individual cages; all animals consumed standard rodent diet and tap water. Body weight, blood glucose and insulin levels were recorded weekly. All animals were cared according to the Guiding Principle in the Care and Use of Animals.

\section{a- Treatments:}

Treatments were initiated soon after establishment of diabetes 3days after administration of Streptozotocin.

\section{b- Animal grouping:}

Forty healthy adult male albino rats weighing from (150-200 gm) were divided into four groups, each consisted of 10 rats:

Group (1): Considered the normal control); feeding on normal diet (injected i.p. with citrate buffer).

Group (2): Considered the model control (diabetic group): group of animals suffered from diabetes.

Group (3): (Green tea diabetic groups): groups of animals suffer from diabetes supplemented with green tea (EGCG) and examined after $3 \&$ 6weeks. 
Group (4): (Curcumin supplemented diabetic groups): groups of diabetic animals supplemented with curcumin and examined after $3 \& 6$ weeks.

\section{Natural Antioxidants:}

\section{a- Green tea extract (EGCG)}

Green tea extract was obtained in the form of tablets each tablet contains $300 \mathrm{mg}$ of green tea dry extract. In the present study green tea extract was prepared by dissolving the tablets in distilled water at dose level $45 \mathrm{mg} / 1 \mathrm{ml} / \mathrm{rat} / \mathrm{day}$. It was administered daily by gavages. The dose for rats was calculated according to the Paget's formula on the basis of the human dose (Paget and Barnes, 1964).

\section{b- Curcumin:}

Curcumin product was prepared as a suspension solution at dose level $300 \mathrm{mg} / \mathrm{ml}$ $\mathrm{H}_{2} \mathrm{O}$. Each experimental animal gavages $1 \mathrm{~cm}$ /day by steel tube at a dose level of $300 \mathrm{mg} /$ $\mathrm{Kg} /$ rat (Paget and Barnes, 1964).

\section{Chemicals:}

Streptozotocin (STZ) was obtained from Sigma Chemical Co. (St. Louis, MO, USA).

\section{Induction of diabetes:}

Diabetes was induced by a single intraperitoneally injection of freshly prepared Streptozotocin (STZ), stored at $4{ }^{\circ} \mathrm{C}$ temperature and protected from environmental extremes (STZ; $45 \mathrm{mg} / \mathrm{kg}$ B.wt.) dissolved in freshly prepared $0.05 \mathrm{M}$ of sodium citrate buffer, $\mathrm{pH}=$ 4.6 (Mitra et al., 1996). Normal blood glucose level was measured in fasting rats before STZ injection (zero-time), then measured again $48 \mathrm{hr}$ after STZ injection to be sure that the rats became diabetic, their weight also must determined before and after injection.
STZ-injected groups considered to be diabetic when blood glucose values were above (250 $\mathrm{mg} / \mathrm{dl})$. The blood glucose level was determined by glucose oxidase method using a one touch basic plus glucometer (Lifescane Ltd., California, USA).

\section{1-Biochemical preparation :}

\section{a- Blood glucose level detection:}

Blood glucose level and weight of every rat were determined every week. Blood sample collected from ocular orbit vein by heparinized heamatocrit capillary tubes.

\section{$\underline{\text { b- Insulin estimation }}$}

Insulin was assayed in the Medical Service Unit of the National center for Radiation Research and Technology Center (by ELISA kits according to the method of (Byersdorfer, $\boldsymbol{e t}$ al., 2005) and based on the sandwich principle.

\section{2- Histopathological preparation.}

The sacrificed animals were quickly dissected. Sample of the liver and pancreas were removed and fixed in $10 \%$ neutral formalin for 24 hours and thin sections were prepared ( $5 \mu$ thick) and stained with Hematoxylin and Eosin (Jamshidzadeh et al., 2008).

\section{3-Histochemical preparation:}

\section{1-Deoxyribonucleic acid (DNA)}

DNA was histochemicaly determined by applying Feulgen's technique (Pearse, 1985).

\section{2- Polysaccharids PAS reaction :}

Polysaccharids were demonstrated following the application of periodic acid schiff's (PAS) technique (Humason, 1972). 


\section{Results:}

Table 1, showed remarkable differences in body weight, glucose and insulin levels among the four groups. Figure (a) showing decreased body weight in group [2] which is diabetic, a gradual significant increase in the body weight can be recognized in both treated groups. Blood Glucose: of STZ diabetic rat was significantly increased when compared to the normal control, while blood glucose of the treated diabetic rat groups $[3,4]$ was significantly decreased when compared with diabetic group and nearly normal when compared to normal control Figure (b). Meanwhile, Figure (c) revealing a statistical decrease in serum insulin level of group [2] when compared with the normal control. On the other hand group [3] [green treated diabetic group] showed a slight increase in the insulin level on the third week and becoming more significant on the six week. At the same level, curcumin showed ameliorating effect on the third week and came to be nearly normal on the six week.

Table 1: Means values of the body weight, glucose, and insulin in the four groups

\begin{tabular}{|c|c|c|c|c|c|}
\hline Parameters & $\begin{array}{l}\text { Period of } \\
\text { time }\end{array}$ & $\begin{array}{ll}\text { Group } & 1 \\
\text { Normal } & \\
\text { control } & \end{array}$ & $\begin{array}{c}\text { Group2 } \\
\text { Diabetic } \\
\text { (72hrs) } \\
\text { afterSTZ } \\
\text { injection }\end{array}$ & $\begin{array}{l}\text { Group3 } \\
\text { Green tea } \\
\text { diabetic }\end{array}$ & $\begin{array}{c}\text { Group4 } \\
\text { Curcumin diabetic }\end{array}$ \\
\hline \multirow[b]{2}{*}{$\begin{array}{l}\text { Glucose } \\
{[\mathrm{mg} / \mathrm{dl}]}\end{array}$} & 3 Weeks & \multirow[b]{2}{*}{$86.67 \pm 2.19^{\mathrm{b}}$} & \multirow[b]{2}{*}{$300 \pm 11.35^{\mathrm{a}}$} & $99.33 \pm 4.22^{\mathrm{b}}$ & $90.22 \pm 2.11^{\mathrm{b}}$ \\
\hline & 6 Weeks & & & $95.67 \pm 0.92^{\mathrm{b}}$ & $88.56 \pm 1.4^{\mathrm{b}}$ \\
\hline \multirow[b]{2}{*}{$\begin{array}{l}\text { Insulin } \\
{[\mathrm{mg} / \mathrm{ml}]}\end{array}$} & 3 Weeks & \multirow[b]{2}{*}{$0.322 \pm 0.012^{\mathrm{b}}$} & \multirow[b]{2}{*}{$0.173 \pm 0.015^{\mathrm{a}}$} & $0.247 \pm 0.034^{\mathrm{a}}$ & $0.211 \pm 0.001^{\mathrm{a}}$ \\
\hline & 6 Weeks & & & $0.355 \pm 0.029^{b}$ & $0.291 \pm 0.009^{b}$ \\
\hline \multirow{2}{*}{$\begin{array}{l}\text { B.WT } \\
\text { [gm] }\end{array}$} & 3 Weeks & $149.5 \pm 8.02^{\mathrm{b}}$ & $139 \pm 4.12^{\mathrm{a}}$ & $164 \pm 15.30^{\mathrm{b}}$ & $170.45 \pm 16.05^{\mathrm{b}}$ \\
\hline & 6 Weeks & $157 \pm 11.14^{\mathrm{a}}$ & $137.67 \pm 8.04^{\mathrm{a}}$ & $185 \pm 4.83^{\mathrm{ab}}$ & 190. $25 \pm 3.24^{\mathrm{ab}}$ \\
\hline
\end{tabular}

- Means carrying the same letter [superscript] within the same row are non significantly different from each other's [P > 0.05].

- Means carrying different letters [superscripts] within the same row are [significantly or high significantly] different from each other's [significant at $[\mathrm{P} \leq 0.05]$ and highly significant at $[\mathrm{P} \leq 0.01]$. 
Cytological And Histochemical Studies On Rat Liver....

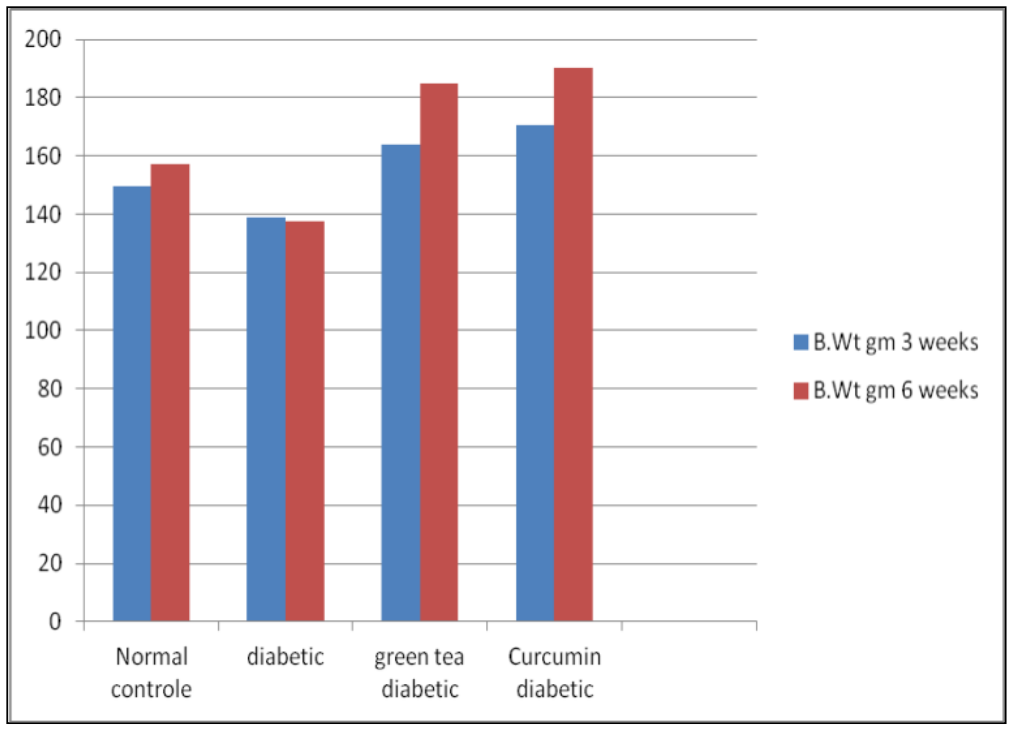

Figure a: Illustrating the changes in the body weight in the four groups used in this experiment

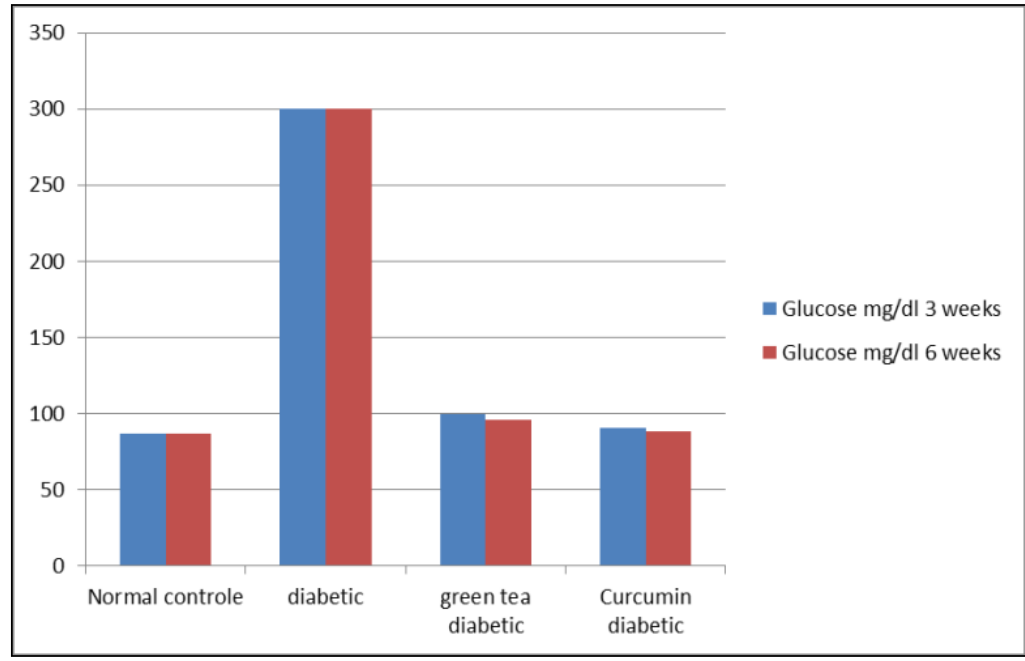

Figure b: Illustrating the variation of the glucose level in the four groups of the experiment

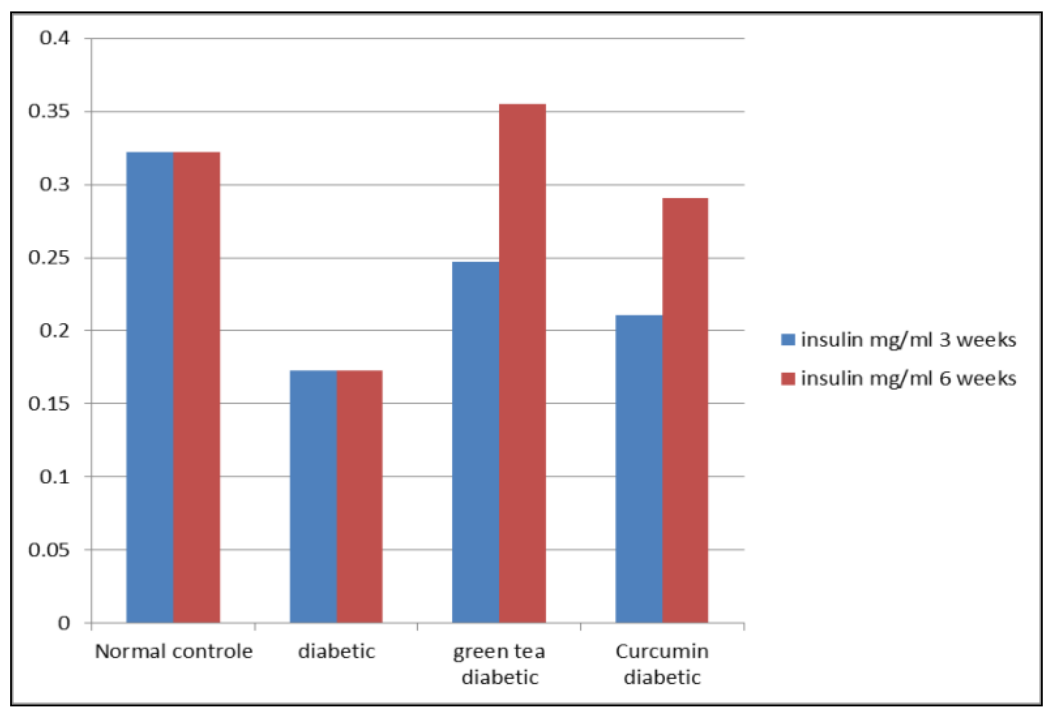

Figure c Illustrating the variation in the serum insulin level in the four groups 


\section{Pathological Observations}

\section{Plate (I) liver:}

Examined sections of normal control rat group [1] show that most of the cells contain a central rounded nuclei, while some are binucleated. The blood sinusoids are present between the cords. The sinusoidal endothelium is formed of endothelial lining cells and the phagocytic kupffer cells (Figure 1G1). Liver sections from diabetic rats [G 2] showed severe injury illustrated in mononuclear cell infiltrate extending through hepatic tissue, Kupffer cell appeared engulfing debris of the degenerated hepatocytes and hyperplasia of bile duct (Figure 2aG2). Also, obvious fatty change could be seen (Figure 2bG2). Examined sections of group [3] showed graduate restoration of hepatocytes and blood sinusoids, most of the hepatocytes were healthy and seem to be regular (Figures 3G3,4G3) .Mononuclear cell infiltration and pyknotic nuclei are still observed (Figure 3G3). On the other hand, sections from group [4] illustrated the curative effect of curcumin, in which most of the hepatocytes were relatively in regular state ,but dilated blood vessels (in 3 and 6 weeks) and hydropic degeneration were still observed (Figures 5 G4, 6G4).

\section{Plate (II) pancrease:}

Pancreatic section from group [1] showed normal pancreatic structure with regular islets of Langerhans and acini (Figure 1G1). Pancreatic sections from group [2] which is treated with STZ showing disorganization of the structure of the endocrine and exocrine glands illustrated in hypocellularity of islets of Langerhans with damaged and necrotic pancreatic acini, (Figure
2G2). On the other hand sections from group [3] at two interval times $3 \& 6$ weeks there were a gradual restoration of pancreatic endocrine cells, degeneration in some of the pancreatic acini was still observed (Figures 3G3,4G3 ). More over pancreatic cells of group [4] declared that curcumin have much better effect after 3 weeks, the cells showed healthy structure (Figure 5G4). Mean while, the examined pancreatic sections treated with curcumin after 6 weeks showed atrophied islet, infiltration of blood cells through cells of Langerhans islets (Figure 6G4).

\section{Histochemical observations}

Charbohydrate detection [polysaccharides] [PAS]

\section{Plate (III) liver:}

Normal content of PAS (+ve) materials was detected in (Figure aG1). Hepatocytes of diabetic rats showed marked depletion in the PAS (+ve) materials (Figure bG2). But hepatocytes of diabetic rats which treated with green tea (for 3 and 6 weeks) or curcumin (for 6 weeks) restore their normal content of PAS (+ve) materials (Figures c,dG3 \& fG4) except those of group (4) which showed decrease content of this material (Figure eG4).

\section{DNA content:}

\section{Plate (IV) liver:}

Liver sections of group [1] showing normal DNA content (Figure aG1), while group [2], showed decreased DNA content of the liver tissue (Figure bG2). Liver sections from group [3], showed gradual elevation in DNA content (Figures c,d G3). Sections from group [4], showed normal DNA content of some hepatocytes, while some of them showed less stain affinity (Figure e,fG4). 


\section{Plate $(V)$ pancrease:}

On the other hand examined pancreatic sections from group [3] showed gradual increase in DNA content of the aciner cells 3 and 6 weeks after treatment compared to normal, while sections that were treated with curcumin were retain its normal pattern at the 6 weeks of treatment (Figures gG1, hG2, iG3, jG3, kG4, IG4).

\section{Discussion:}

Diabetes mellitus is a complicated group of disorders characterized by hyperglycemia, that increase the global prevalence in the present century. Diabetes mellitus type 1 is an autoimmune disorder caused by lymphocytic infiltration and beta cells destruction within the pancreatic islets of Langerhans. The pancreatic B-cells are lost in numbers and volume, then severe permanent insulin deficiency results. Oxidative stress is produced under diabetic conditions and possibly causes various forms of tissue damage in patients with diabetes. The oxidative stress in the progression of pancreatic $\mathrm{B}$-cell dysfunction in type 1 diabetes is now the most common cause of liver disease. However, evidences suggest that oxidative stress and free radicals play an important role in the pathogenesis of diabetes mellitus and diabetic complications (Halliwell and Gutteridge, 1989). The STZ diabetic mice exhibited persistent hyperglycemia which is the main diabetogenic factor and contributes to the increase in oxygen free radicals by autoxidation of glucose. Hyperglycemia also generates reactive oxygen species, which in turn, cause lipid peroxidation and membrane damage, also diabetes increases oxidative stress in many organs, especially in the liver (Tolman et al., 2007).

Liver is one of the most important organs that maintains blood glucose levels within normal limits thus enhancement of blood sugar yield to imbalance the oxidation-reduction reactions in hepatocytes, so that, hyperglycemia through increasing in AGEs (advanced glycation end products) facilities free radicals production via disturbance in ROS (reactive oxygen species) production. Hence, it reveals that, diabetic hepatic injuries result from several agents and is not controllable only via inhibition of hyperglycemia. Namely, although in early stages of diabetes, tissues injuries are induced via hyperglycemia, but its progress in latter stages is not related to hyperglycemia. Therefore, monitoring of blood glucose levels solely is not sufficient in retarding diabetes complications. Thus, a suitable drug must have both antioxidant and blood glucose decreasing properties (Vestra and Fioretto, 2003; Kalia et al., 2004; Cameron et al., 2005; Jandeleit-Dahm et al., 2005; Ramesh and Pugalendi, 2006; Liu et al., 2008). In accordance to our results blood glucose level of treated diabetic rats were significantly decreased when compared with diabetic group and reached to somewhat normal levels when compared to normal control. On the other hand serum insulin level showed a decrease when compared with the control, diabetic groups showed none significant change. These finding confirmed the opinion that curcumin and green tea in diabetes rats cause, degradation of liver glycogen and increase gluconeogenesis, while glucose utilization is inhibited (Patrick et al., 2008; Kumar et al., 
2011). Glucose 6-phosphatase increases in the liver facilitating glucose release into the blood. Green tea is considered to be anti-inflammatory, antioxidative, antimutagenic and anticarcinogenic (Benelli et al., 2002; Weisburger and Chung, 2002; Muranyi et al., 2003). In the present studies the differences in body weight among diabetic and treated groups, diabetic group showed a decrease in the body weight, this may due to lack of insulin in the blood, the sugar cannot enter inside the cells, thus increasing the percentage of sugar in the blood. The body tries to get rid of excess sugar by excretion in the urine. The excess secretion of urine will lead to the reduced amount of water in the body and this will reduce the body weight. Many studies showed that this loss of weight may be related to significant hypoglycemic effect in diabetic rats, glucose intolerance could arise from either a defect in insulin secretion as in case of insulin dependent diabetes (Type I) or a defect in insulin resistance (receptor or postreceptor defect) as in case of non insulin dependent diabetes mellitus (Type II) (Tsuneki et al., 2004; Wu et al., 2004; Ryu et al,. 2006). On the other hand a gradual significant increase in the body weight was observed in the other treated groups (groups 3,4), this may be due to the retained levels of glucose and insulin levels in green tea and curcumin treated animals (Baluchnejadmojarad et al., 2012). In the present studies kupffer cells in diabetic animal appeared engulfing debris of degenerated hepatocytes with hyperplasia of the bile duct this finding agree with those of Cameron et al.(2005). The fatty changes in the centrilobular portions of the livers in diabetic group was realized by Ramesh et al.(2007). In our results the green tea treatment in diabetic rats showed no considerable fatty changes indicating the protective effect of green tea against hepatic complications of diabetes thie results confirmed by Aybar et al.(2001). In the present studies green tea and curcumin found to have graduate restoration and ameliorating effect and it is time dependant. Also it is clearly observed that, curcumin give more ameliorating effect. Meghana et al. (2007) reported the effectiveness of curcumin in reducing secondary complications in STZ induced diabetic animals. Moreover, the curcumin has been demonstrated in prevention isolated beta cell death and dysfunction induced by STZ (Meghana et al., 2007; Malee Chanpoo et al., 2010).

Our results are in accordance with Kalia et al.( 2004) who stated that the pancreatic cells of diabetic rats revealed reduction in number of islets, degeneration of B-cells, hydropic degeneration, clumping of B-cells, pyknosis and necrosis, can be attributed to the partial damage of Streptozotocin to some beta cells. Streptozotocin produced an incomplete destruction of pancreatic beta cells even though rats became permanently diabetic. Also, Patrick et al. (2008) found that pathological examination of STZ diabetic rats showed reduced number of islets of Langerhans and degranulation of Bcells, hydropic degeneration, pyknosis and necrosis, these findings are in accordance with our findings which reveled reduced number of cells of islets of Langerhans, presence of damaged pancreatic acini, pyknosis and necrosis. Our study also come to the fact that excess use of curcumin in diabetic animal may 
cause reverse effect this can easily seen in examined section of group (4) treated for 6 weeks.

Some studies had reported that Streptozotocin enters the beta cells via a glucose transporter (GLUT2) and causes alkylation of DNA damage which induces activation of poly ADPribosylation, a process that is more important for the diabetogenecity of Streptozotocin than DNA damage itself. Poly ADP-ribosylation leads to depletion of cellular NAD+ and ATP. Enhanced ATP dephosphorylation after Streptozotocin treatment supplies a substrate for xanthine oxidase resulting in the formation of super oxide radicals. Consequently, hydrogen peroxide and hydroxyl radicals are generated (Szkudeelski, 2001). Furthermore Streptozotocin liberates toxic amounts of nitric oxide that inhibits aconitase activity and participates in DNA damage. As a result of the Streptozotocin action, beta cells undergo destruction by necrosis. Other studies carried on diabetic liver indicated that cytotoxic effects of Streptozotocin are dependent upon DNA alkylation by site-specific action with DNA bases and by free-radical generation during Streptozotocin metabolism these findings were in accordance with (Benneth and Pegg, 1981; Szkudeelski, 2001; Bolzan and Bianchi, 2002). The findings of the present study agree with these findings which showed depletion in DNA in both liver and pancreatic cells. In conclusion, our study provides clear evidence of pancreatic islets growth to respond to curcumin and green tea treatment in diabetic rats at 3,6 weeks post treatment. More over Our observation is appropriate for the further molecular studies and search of new factors to evaluate the implicated mechanisms in the pancreatic islets modifications in the future that could lead to provide new therapeutic agents of diabetes mellitus.

\section{References:}

-Aybar M., Sanchej Riera A., Grau A and Sanchez S (2001): Biochemical and histomorphological study of streptozotocin-induced diabetes mellitus in rabbits. J. Ethnopharmacol., 27:243-275.

-Baluchnejadmojarad T., Nasri S., Roghani M; Balvardi $M$ and Rabani T (2012): Chronic cyanidin-3-glucoside administration improves shortterm spatial recognition memory but not passive avoidance learning and memory in streptozotocindiabetic rats. Phytother. Resdoi., 1002:3702-3719.

-Benelli R; Vene R; Bisacchi D; Garbisa S and Albini A (2002): Anti-invasive effects of green tea polyphenol epigallocatechin-3-galleate [EGCG], a natural inhibitor of metallo and serine proteases. Biol. Chem., 383:101-105.

-Benneth R and Pegg A (1981): Alkylation of DNA in rat tissues following administration of streptozotocin. Cancer Res., 41:2786-2790

-Bolzan A and Bianchi M (2002): Genotoxicity of streptozotocin. Mutat. Res., 512:121-134.

-Byersdorfer C; Schweitzer G and Unanue E (2005): Diabetes is predicted by the beta cell level of auto antigen. J. Immunol., 175:4347-4354.

-Calabrese V (2003): Nutritional antioxidants and the heme oxygenase pathway of stress tolerance: novel targets for neuroprotection in Alzheimer's disease. J. Biochem., 52(4):177-181.

-Cameron N; Gibson T; Nangle $M$ and Cotter $M$ (2005): Inhibitors of advanced glycation end product formation and neurovascular dysfunction in experimental diabetes. Ann. N. Y. Acad. Sci., 1043:784-792.

-Crespy V and Williamson G (2004) A review of the health effects of green tea catechins in vivo animal models. J. Nutr., 134:3431-3440.

-Halberstein R A (2005) Medicinal plants: historical and cross-cultural usage patterns. Ann. Epidemiol., 15: 686-699.

-Halliwell B and Gutteridge J (1989): Free Radicals in Biology and Medicine. Clarendon Press, Oxford.

-Harris E H (2005): Protective effects of Green tea extract against hepatic tissue injury in streptozotocininduced diabetic rats. Clinical diabetes, 23[3]:115119.

-Hirosh T; Mitsuy I; Mi T; Jin E; Tosiyasu S and Ikuko $K$ (2004): Effect of green tea on blood glucose levels and serum proteomics patterns in diabetic mice and on glucose metabolism in healthy humans. B.M.C. Pharma., 4:18-30.

-Humason G (1972): Animal Tissue Techniques. $3^{\text {rd }}$ ed. Freeman C ompany.San Francisco, pp:327-328. 
-Hiserodt S; Ali G; Hawa Z and Jaafar E (2011): Antioxidant potential and anticancer activity of young ginger [Zingiber officinale Roscoe] grown under different $\mathrm{CO}_{2}$ concentration. J. of Medicinal Plants Research, 5[14]: 3247-3255.

-Jamshidzadeh A; Baghban M; Azarpira N; Mohammadi A and Niknahad $H$ (2008): Effects of tomato extract on oxidative stress induced toxicity in different organs of rats. Food Chem. Toxicol., 46[12]: 3612-3615.

-Jandeleit-Dahm K; Lassila $M$ and Allen $T$ (2005): Advanced glycation end products in diabetesassociated atherosclerosis and renal disease: interventional studies. Ann. N. Y. Acad. Sci., 1043:759-766.

-Kalia K; Sharma S and Mistry K (2004): Nonenzymatic glycosylation of immunoglobulins in diabetic nephropathy. Clinica. Chimica. Acta., 347[1-2]:169-176.

-Kanitkar M; Gokhale K; Galande S; Bhonde R and Novel R (2008): Role of curcumin in the prevention of cytokine-induced islet death in vitro and diabetogenesis in vivo. Br. J. Pharmacol., 155: 702-712.

-Kumar B; Gupta S; Nag T; Srivastava S and Saxena R (2011): Green tea prevents hyperglycemiainduced retinal oxidative stress and inflammation in streptozotocin-induced diabetic rats. Ophthalmic Res., 47[2]:103-108.

-Liu H; Tang X; Dai D and Dai Y (2008): Ethanol extracts of Rehmannia complex [Di Huang] containing no corni fructus improve early diabetic nephropathy by combining suppression on the ETROS axis with modulate hypoglycemic effect in rats. J. Ethnopharmacol. 118[3]:466-472.

-Lodha R and Baggha A (2000): Traditional Indian systems of medicine. Ann. Acad. Med. Singapore, 29:37-41.

-Malee C; Hattaya P; Busaba $P$ and Vipavee A (2010): Effect of Curcumin in the Amelioration of Pancreatic Islets in Streptozotocin-Induced Diabetic Mice. J. Med. Assoc. Thai., 93 (6):152-159.

-Meghana K; Sanjeev G and Ramesh B (2007): Curcumin prevents streptozotocin-induced islet damage by scavenging free radicals: a prophylactic and protective role. Eur. J. Pharmacol., 577: 183-191. -Mitra S; Gopumadhavan S; Muualidhar T; Anturlikar S and Sujatha M (1996): Effect of a herbomineral preparation D-400in streptozotoci induced diabetic rats. J. Ethnopharmacol., 54: 41-46.

-Muranyi M; Fujioka M; QingPing H; Han A and Yong G (2003): Diabetes activates cell death pathway after transient focal cerebral ischemia. Ann. N. Y. Acad. Sci., 52:481-486.

-Mutalik S; Sulochana B; Chetana M; Udupa N and Devi V (2003): Preliminary studies on acute and subacute toxicity of an antidiabetic herbal preparation-Dianex. Ann. N. Y. Acad. Sci., 41: 316320.
- Paget G E and Barnes J M (1964): Evaluation of Drug Activity: Pharmaceutics Laurence and Bacharach Eds., vol1, Academic press, New York.

-Panchatcharam M; Miriyala S; Gayathri V and Suguna L (2006): Curcumin improves wound healing by modulating collagen and decreasing reactive oxygen species. Mol. Cell Biochem., 290:87-96.

-Pari L and Murugan P (2005): Effect of tetrahydrocurcumin on blood glucose, plasma insulin and hepatic key enzymes in streptozotocin induced diabetic rats. J. Basic. Clin. Physiol. Pharmacol., 16:257-274.

-Patrick E; Item J; Eyong U and Godwin E (2008): The antidiabetic efficacy of combined extracts from two continental plants: Azadirachta indica and Vernonia amygdalina [African Bitter Leaf]. Am. J. Biochem. Biotechnol., 4: 239- 244.

-Pearse A (1985): Histochemistry. Theoretical and Applied. Vol 2. Analytical Technology. $4^{\text {th }}$ ed. Edinburgh, London, Melbourne, New York, Churchill Livingstone.

-Ramesh B; Pugalendi K (2006): Impact of umbelliferone [7-hydroxycoumarin] on hepatic marker enzymes in streptozotocin diabetic rats. Indian J. Pharmacol., 38[3]:209-210.

-Ramesh B; Viswanathan $P$ and Pugalendi $K$ (2007): Protective effect of Umbelliferone on membranous fatty acid composition in streptozotocin-induced diabetic rats. Eur. J. Pharmacol., 566[1-3]:231-239.

-Ryu O; Lee J; Lee K; Kim H and Seo J (2006): Effects of green tea consumption on inflammation, insulin resistance and pulse wave velocity in type 2 diabetes patients. Diabetes Res. Clin. Pract., 71[3]:356-358.

-Sharma S; Nasir A; Prabhu K and Murthy P (2006): Anti-hyperglycemic effect of the fruit-pulp of Eugenia jambolana in experimental diabetes mellitus. J. Ethnopharmacol., 104: 367-373.

-Szkudeelski T (2001): The mechanism of alloxan and streptozotocin action in B-cells of the rat pancreas. Physiol. Res., 50:536-546.

-Tolman K; Fonseca V; Dalpiaz A and Tan M (2007): Spectrum of Liver Disease in Type 2 Diabetes and Management of Patients with Diabetes and Liver Disease. Diabetes care, 30[3]:734-743.

-Tsuneki H; Ishizuka M; Terasawa M ; Wu J and Sasaoka T (2004): Effect of green tea on blood glucose levels and serum proteomic patterns in diabetic $[\mathrm{db} / \mathrm{db}]$ mice and on glucose metabolism in healthy humans. B.M.C. Pharmacol., 4:18-25.

-Vestra $M$ and Fioretto P (2003): Diabetic nephropathy: renal structural studies in type 1 and type 2 diabetic patients. Internatrional Congress Series, 1253:163-190.

-Weber W; Hunsaker L; Roybal C; Bobrovnikova-Marjon $E$ and Abcouwer $S$ (2006): Activation of NF kappa B is inhibited by curcumin and related enones. Bio. Med. Chem.J., 14:24502461. 


\section{Cytological And Histochemical Studies On Rat Liver....}

-Weisburger J and Chung F (2002): Mechanisms of chronic diseases causation by nutritional factors and tobacco products and their prevention by tea polyphenols. Food Chem. Toxicol., 40:1145-1154. -WHO (2009): Diabetes treatment and control: the effect of public health insurance for the poor in Mexico Sandra G Sosa-Rubí a, Omar Galárraga b \&
Ruy López-Ridaura Bulletin of the World Health Organization.,87:512-519. doi:

10.2471/BLT.08.053256

-Wu L; Juan C C; Ho L; Hsu Y and Hwang L (2004): Effect of green tea supplementation on insulin sensitivity in Sprague-Dawley rats. J. Agric. Food Chem., 52:643-648. 


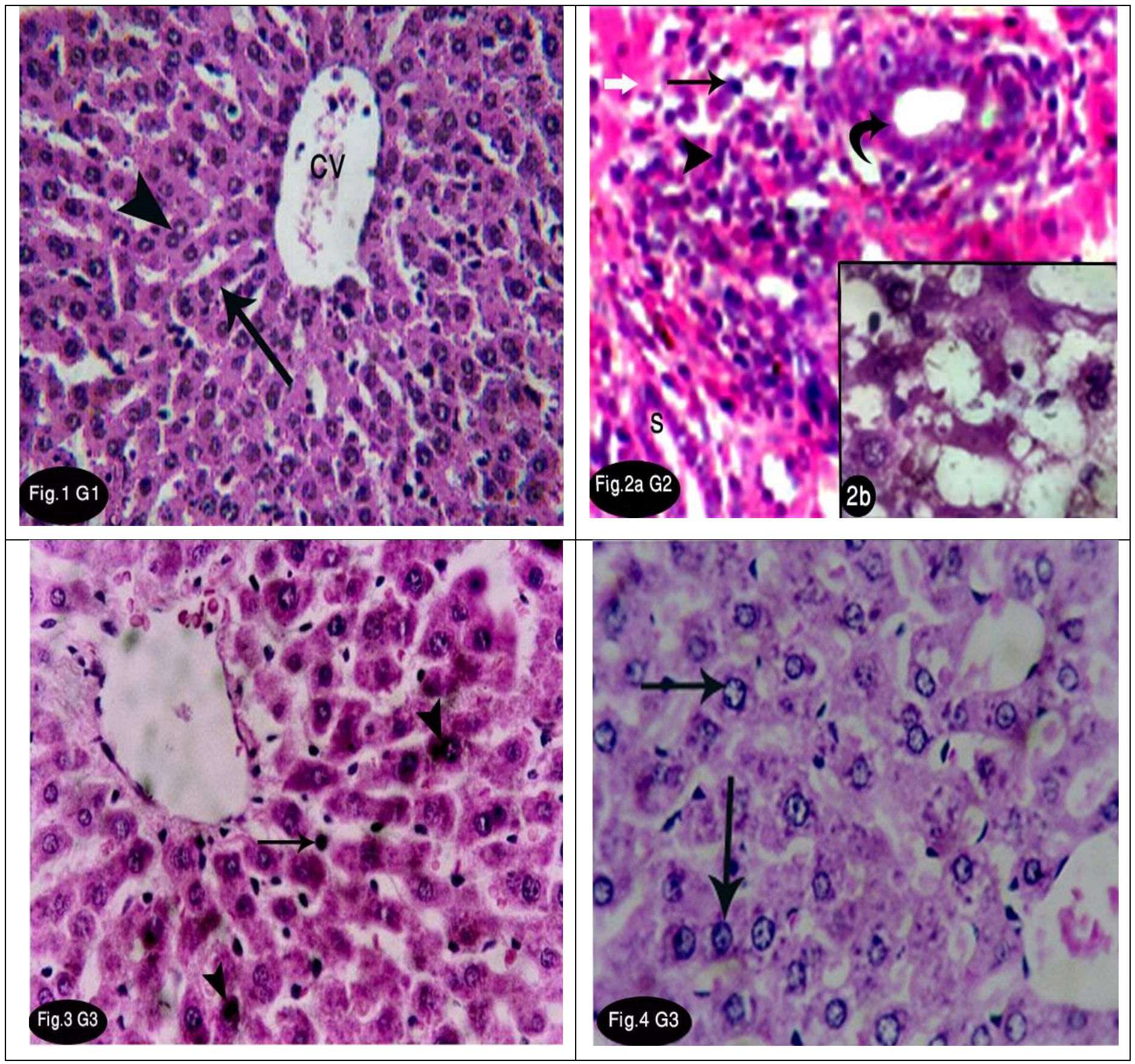

Plate (I): Photomicrographs of sections in liver of albino rats represent Figure [1G1]: section in control rat showing regular hepatic cords (thin arrow), central vein (CV) and binucleated hepatocytes (head arrow) (x 400). Figures [2 G2]: section in diabetic rat showing a- degenerated cells with fading nuclei (white arrow), dilated sinusoids (S) and mononuclear cell infiltrate extending through hepatic tissue (head arrow), Kupffer cell appeared engulfing debris of degenerated hepatocytes (thin arrow) and hyperplasia of the bile duct (curved arrow). (X400), b- Fatty change (X1000). Figure [3 G 3] section from group [3] treated for 3weeks showing: nearly normal appearance of tissue section structure. mononuclear infiltration (thin arrow) and pyknotic nuclei are still observed (head arrow) (x 600). Figure [4 G3] section from group [3] showing: healthy appearance of most of the hepatocytes, most of the nuclei are in mitotic figurers (thin arrows) with increased kuffer cells (X 600). (All the figures H\&E stain). 


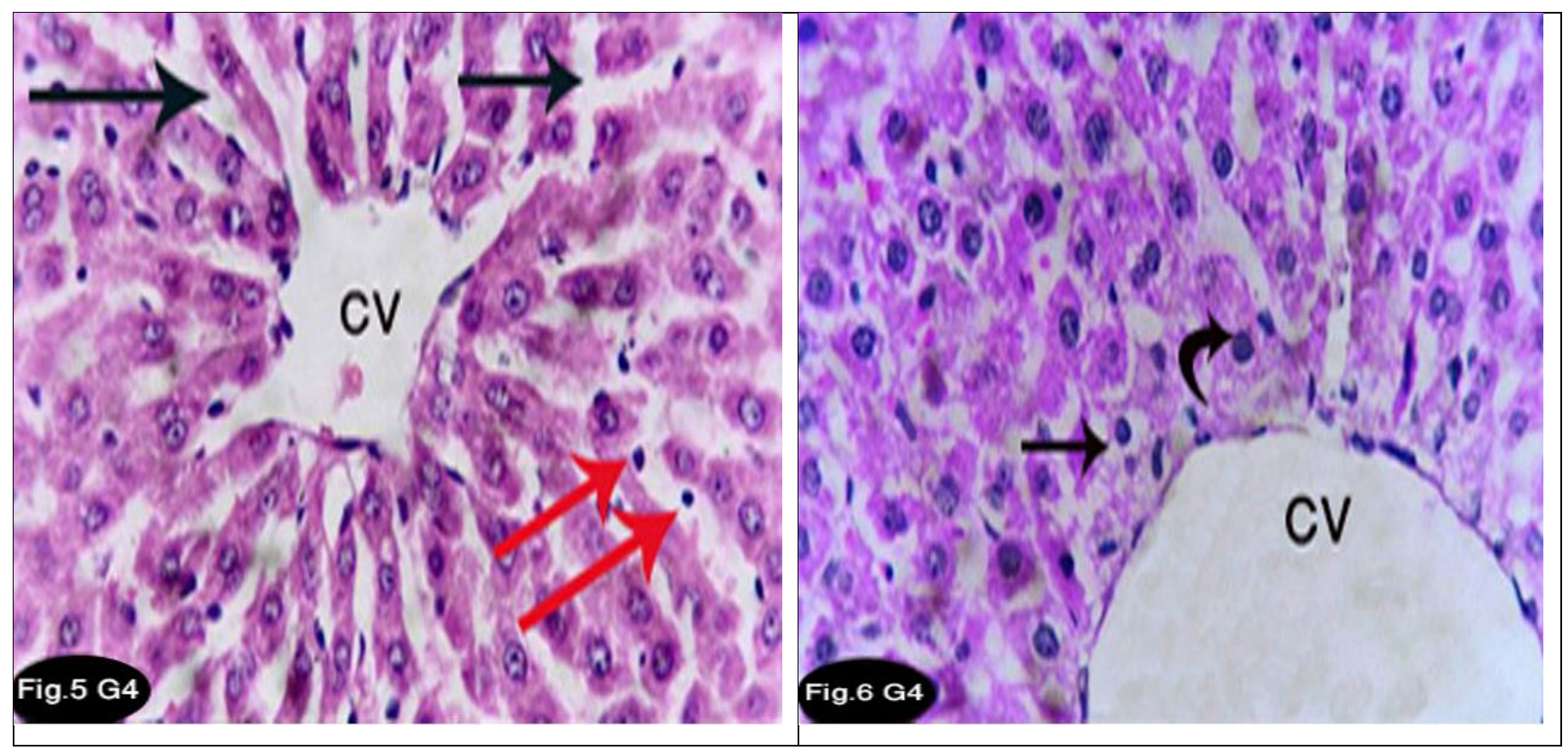

Plate (I): Photomicrographs of sections in liver of albino rats represent Figure [5 G4] section from group [4] showing: some dilated blood sinusoids (thin arrow), increased kuffer cells (red arrow) and faintly stained hepatocytes with disintegrated chromatin. The central vein appeared normal (CV) (x 400). Figure [6G4] section from group [4] treated for 6 weeks showing that most hepatocytes are normal, dilated blood sinusoids (thin arrow), presence of some pyknotic nuclei (curved arrow) ( $x$ 400) (All the figures H\&E stain).
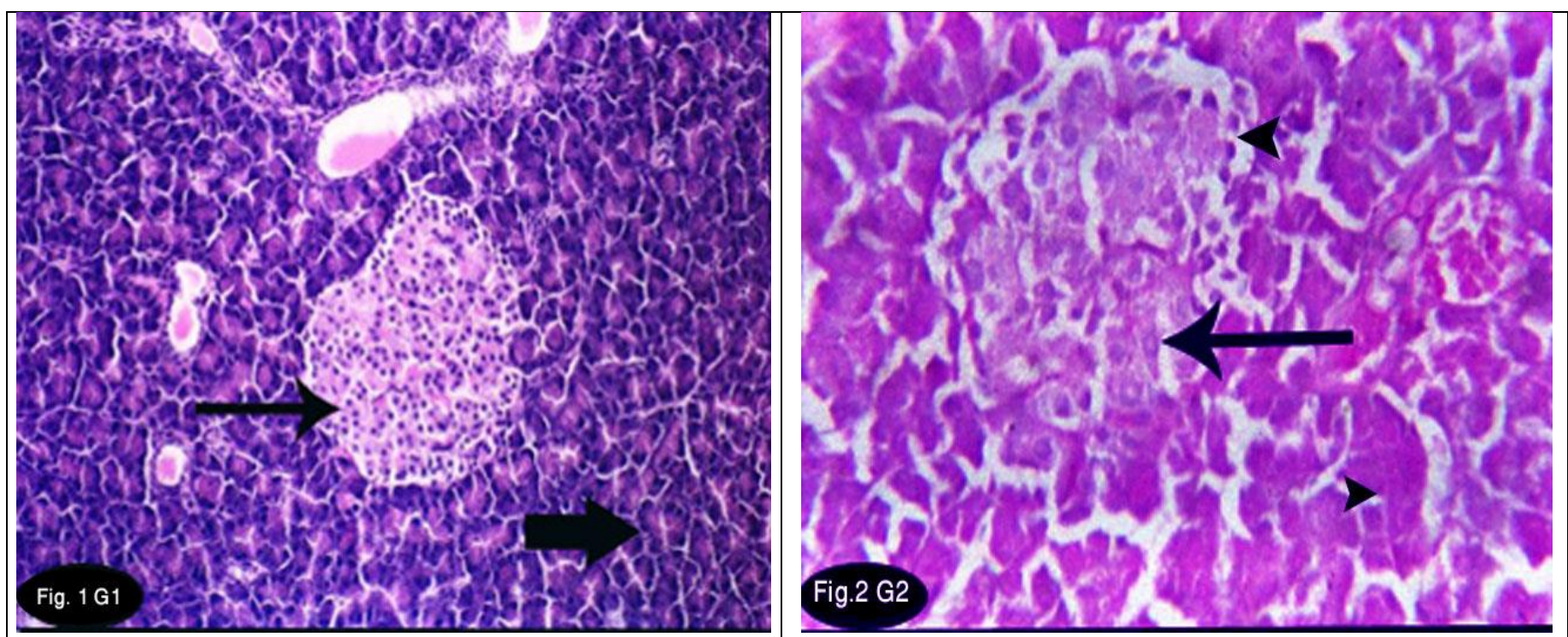

Plate (II): Photomicrographs of sections in pancreas of albino rats represent Figure [1G1]: section in pancreas of a control rat showing: normal appearance of tissue structure. Notice that the normal islets of Langerhans (thin arrow) and normal acini (thick arrow) (x 200). Figures [2 G2]: section in diabetic rat showing: hypocellularity of islets of Langerhans (thin arrow). Some of the pancreatic acini were highly affected (head arrow) (X400). (All the figures H\&E stain). 


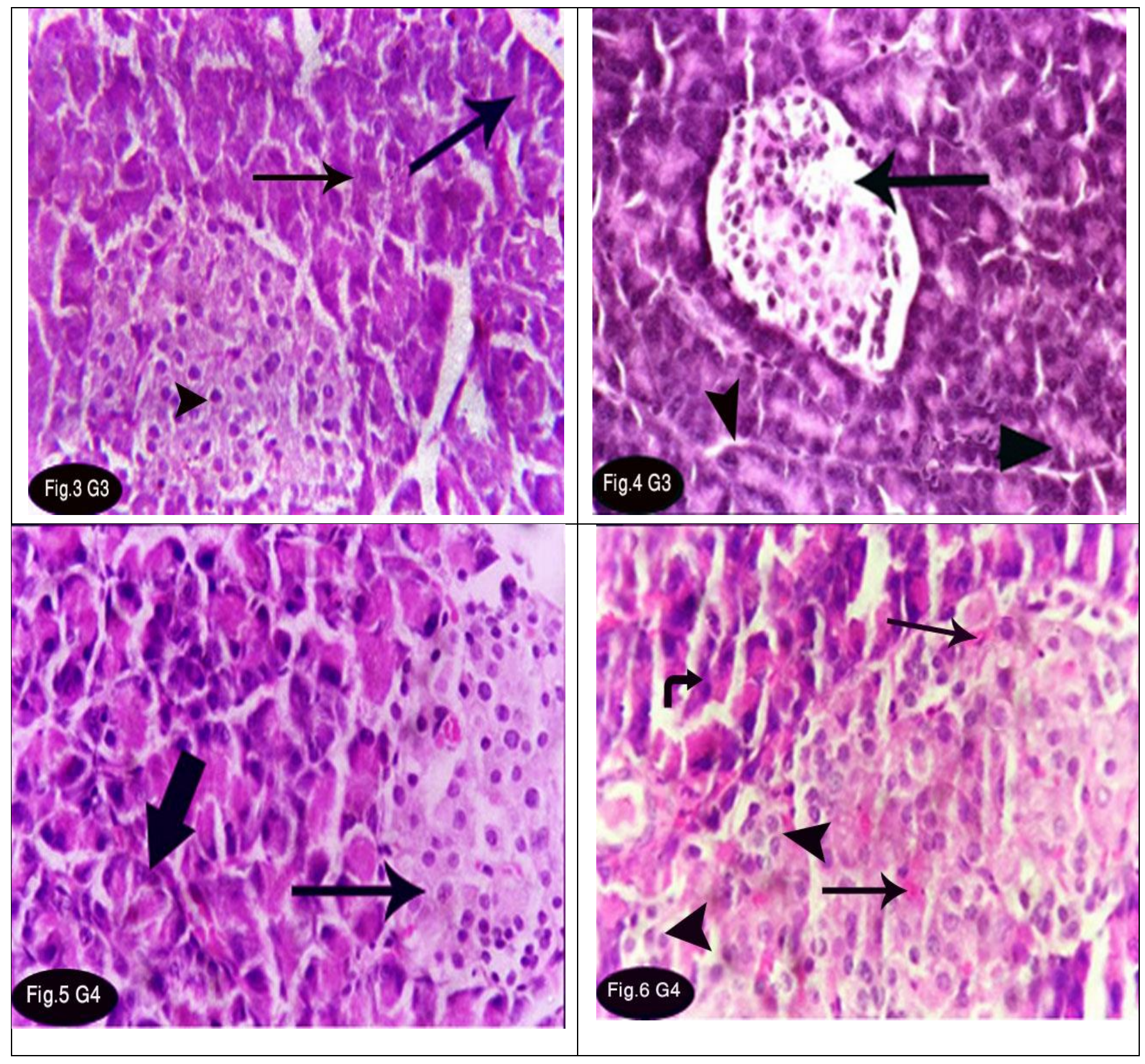

Plate (II): Photomicrographs of sections in pancreas of albino rats represent Figure [3 G 3] section from group [3] treated for 3weeks showing: normal islet of Langerhans (ead arrow), some pancreatic acini are still degenerated (thin arrow) (x 600). Figure [4 G3] section from group [3] treated for 6weeks showing: highly reduced number of cell of islets of Langerhans (thin arrow), pancreatic acini moderately retain its structure (head arrow) (X 400). Figure [5 G4] section from group [4] treated for 3 weeks showing: regular appearance islets of Langerhans cells (thin arrow) and pancreatic acini (thick arrow) (x 400). Figure [6G4]: section from group [4] treated for 6 weeks showing: an atrophied islet. Notice the regularity of most cells (head arrows), infiltration of blood cells through Langerhans islets (thin arrow) and some degenerated acini with highly widened inter aciner spaces (curved arrow) ( x 600). (All the figures H\&E stain). 


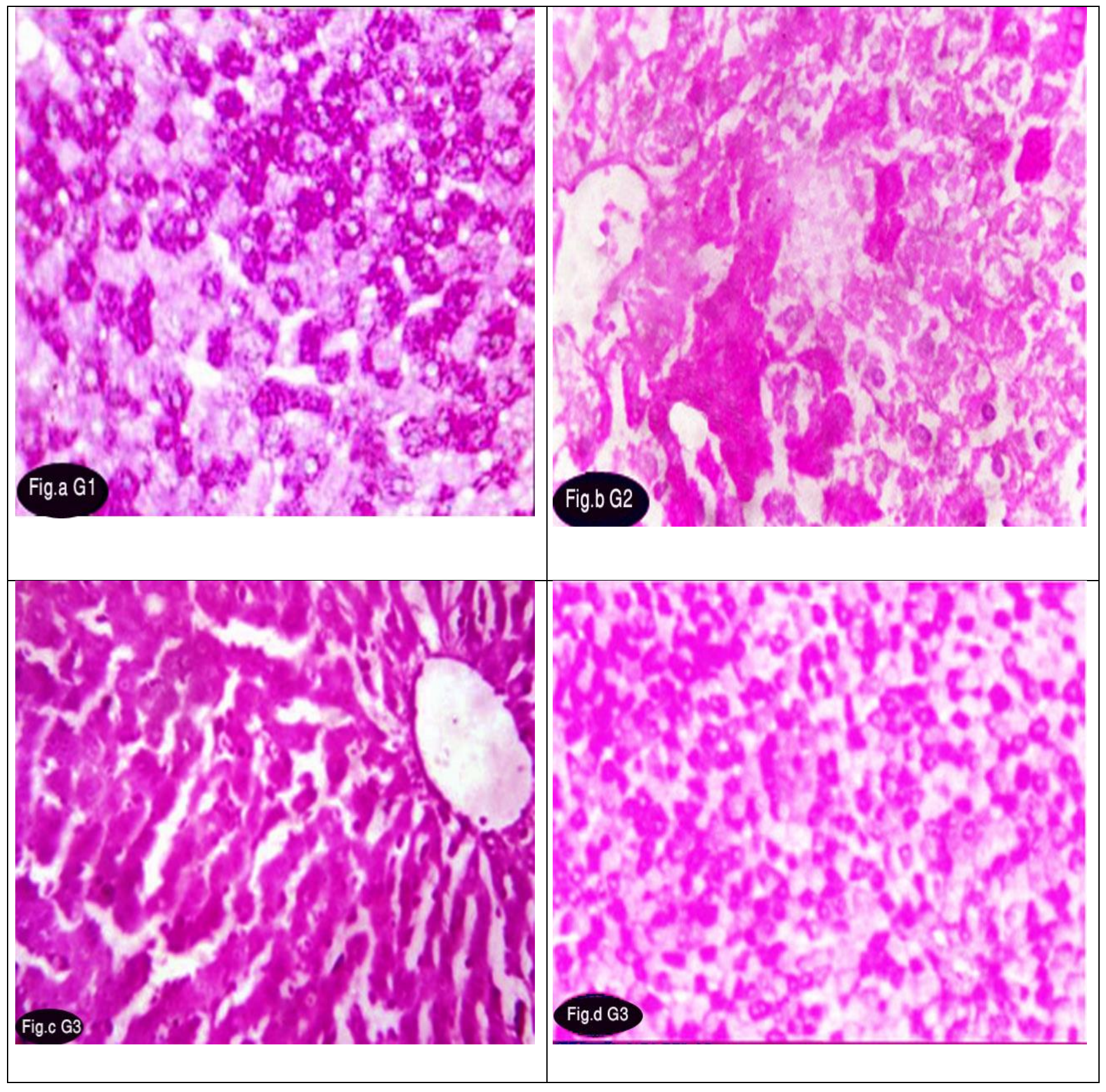

Plate (III): Photomicrographs of sections in liver of albino rats represent Figure [aG1]: section in liver of the control rat showing: normal distribution of PAS (+ve) materials. Figures [b G2]: section in diabetic rat showing: highly decreased PAS (+ve) materials in the liver tissue, some of hepatocytes are destructed and debris of them acquired pale stain affinity. Figure [c G 3] section from group [3] treated for 3weeks showing: increased PAS (+ve) materials in liver tissue. Figure [d G3] section from group [3] treated for 6weeks showing remarkable increase in PAS (+ve) materials. (All the figures PAS stain x 400). 


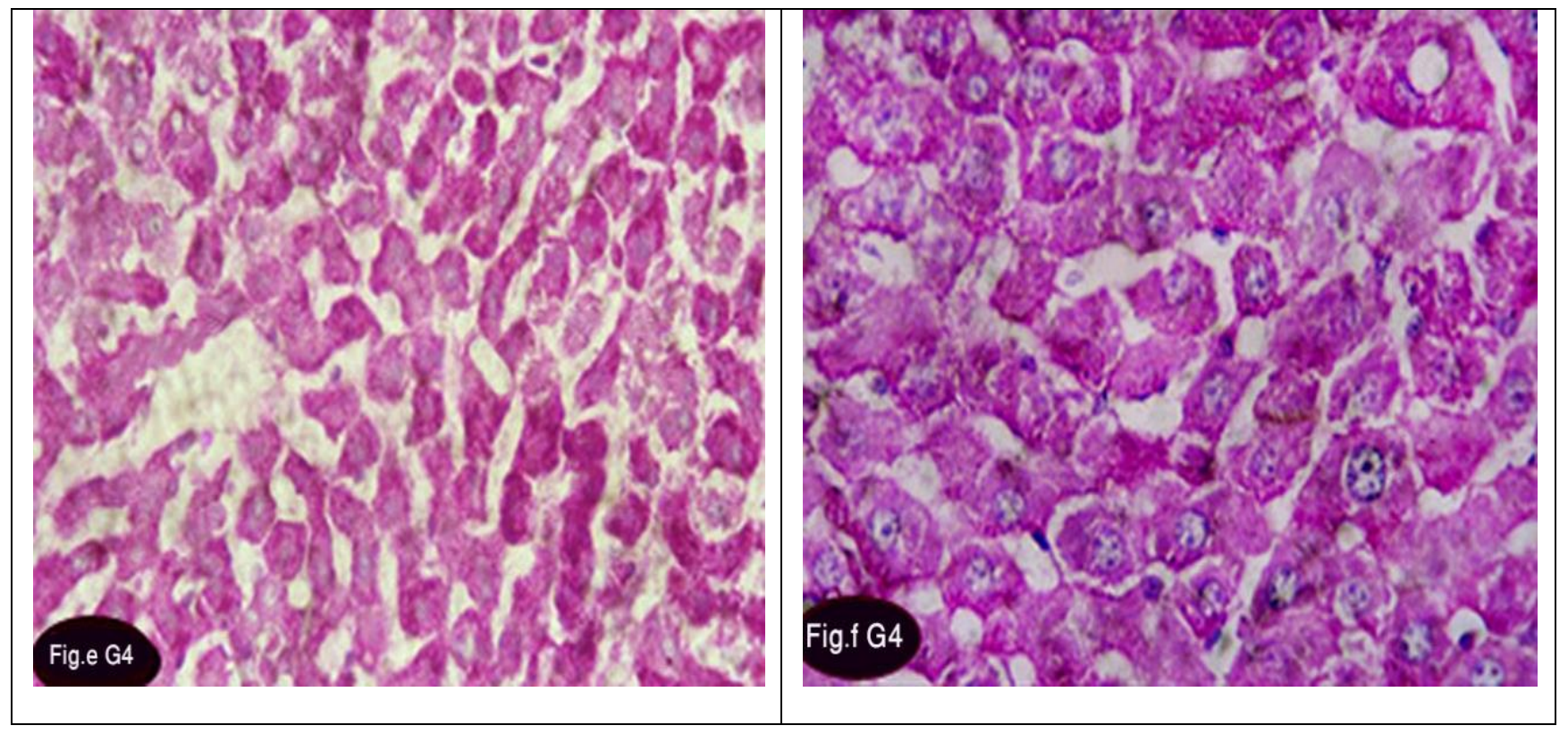

Plate (III): Photomicrographs of sections in liver of albino rats represent Figure [e G4] section from group [4] treated for 3 weeks showing some depleted hepatocytes and decreased PAS (+ve) materials. Figure [fG4]: section from group [4] treated for 6 weeks showing: normal content of PAS (+ve) materials (All the figures PAS stain $\mathrm{x}$ 400).

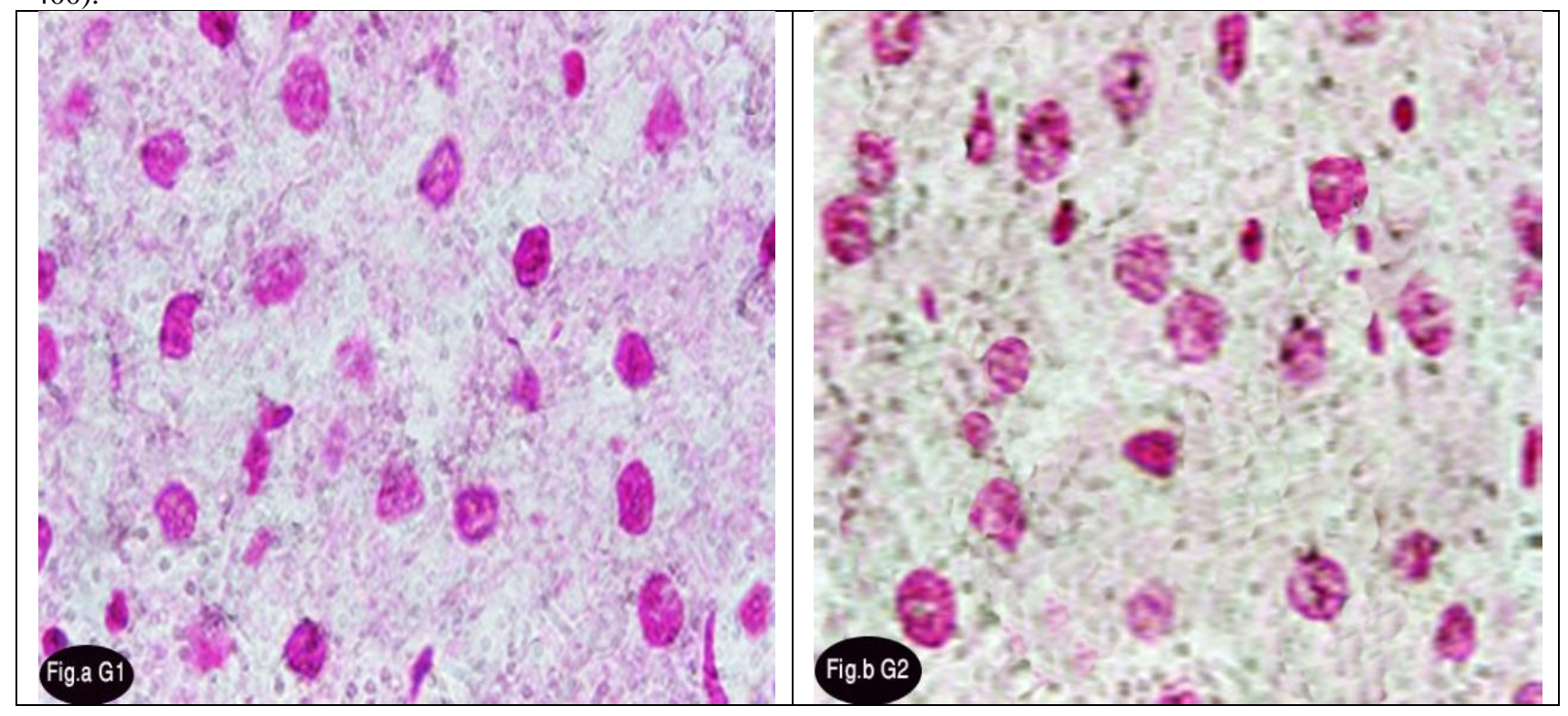

Plate (IV): Photomicrographs of sections in liver of albino rats represent Figure [aG1]: section in liver of the control group showing: regularity in the size of the nuclei, most of them were rounded with normal distribution of chromatin. Figures [b G2]: section in diabetic rat showing reduced stain affinity of DNA materials in some nucle of hepatocytes, others were highly depleted. (All the figures Feulgen reaction x1000). 


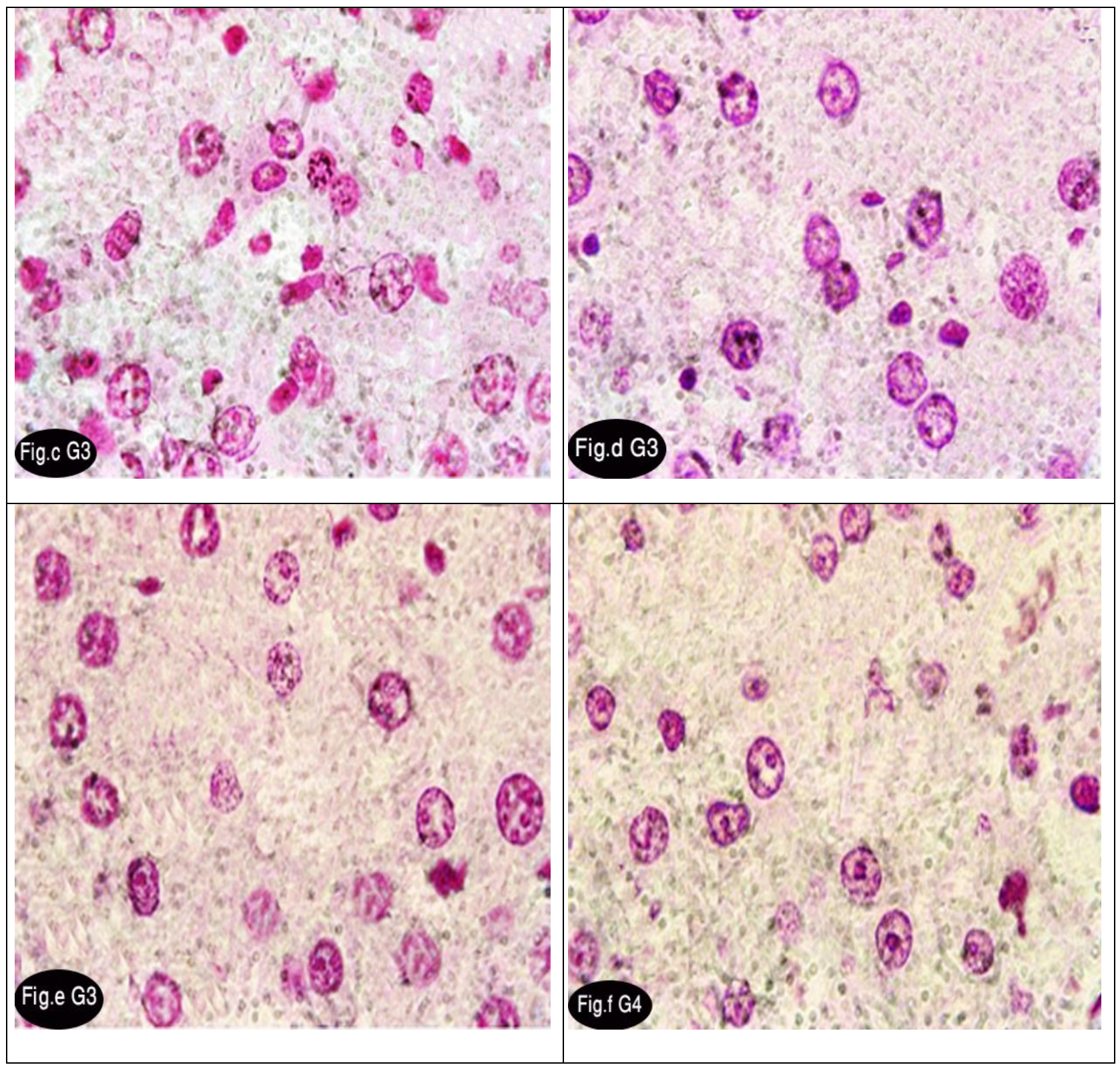

Plate (IV): Photomicrographs of sections in liver of albino rats represent Figure [c G 3] section from group [3] treated for 3weeks showing irregularity in the size of the nuclei; most of them were faintly stained. Figure [d G3] section from group [3] treated for 6weeks showing marked decrease in DNA content compared with the control group. Figure [e,f G4 ] section from group [4] treated for 3 weeks showing that some of hepatocytes restored their normal content of chromatin, others showed less stain affinity. (All the figures Feulgen reaction x1000). 


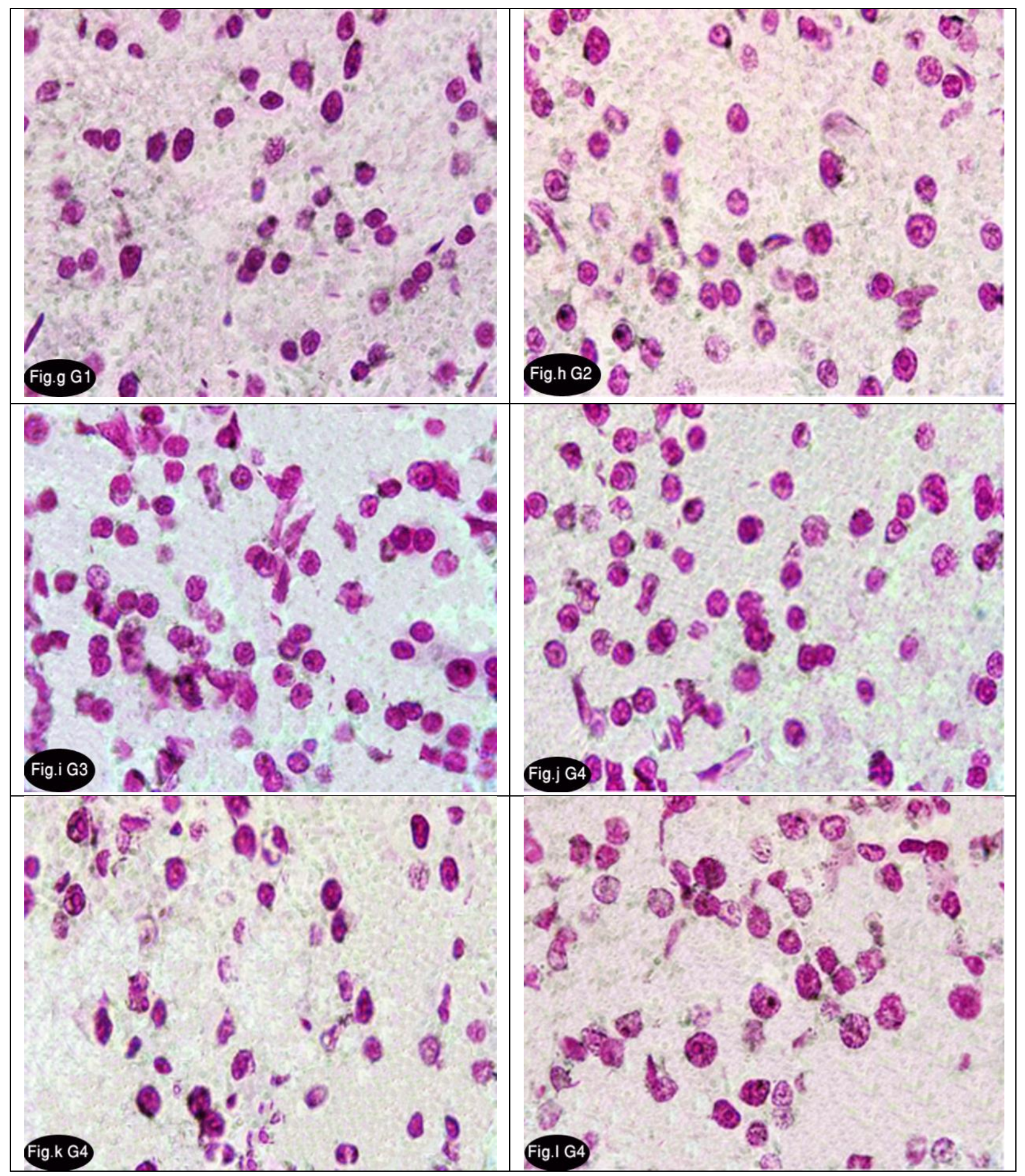

Plate (V): Photomicrographs of sections in pancreastic acini of albino rats represent Figure [gG1]: section in control rat showing: regular distribution of DNA granules. Figures [h G2]: section in diabetic rat showing: decreased DNA content of some nuclei. Figure [i G 3] section from group [3] treated for 3weeks showing moderate increase in DNA content compared with the control group. Figure [j G3] section from group [3] treated for 6weeks showing: somewhat normal DNA content in some cells. Figure [k G4] section from group [4] treated for 3 weeks showing: variable sizes of nuclei with the same intensity of the DNA content. Some cells contained condensed chromatin. Figure [1 G4] section from group [4] treated for 6 weeks showing: somewhat normal content of DNA. (All the figures Feulgen reaction x1000] 


\section{الملخص العربي}

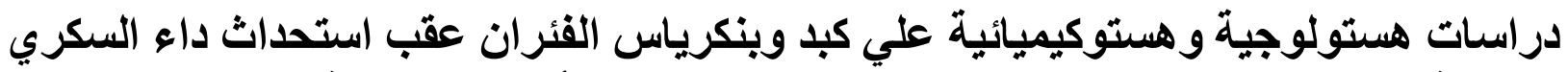

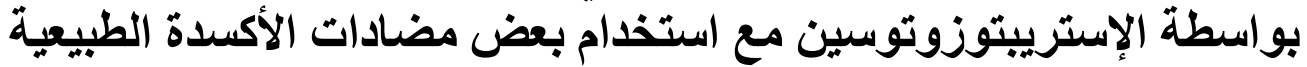

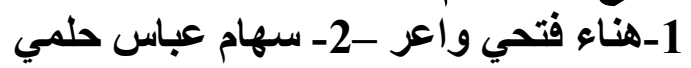

1-هيئة الطاقة الذريةـ المركز القومي للبحوث وتكنولوجيا الإشعاع - مععل بيولوجيا الخلية

2- قسم الخلية و الأنسجة ـ كلية الطب البيطري - جامعة قناة السويس

الخلفية: داء السكري هو اضطر اب في الغدد الصماء الرئيسية ويعتبر مشكلة صحية في معظم البلدان النامية. ويتضح داء السكري في حبو انات التجارب بسبب الضغط التأكسدي الذي ينتج عنه الارتفاع المستمر والمزمن في السكر بالدم والذي يزيد من تخليق الجذور الحرة.

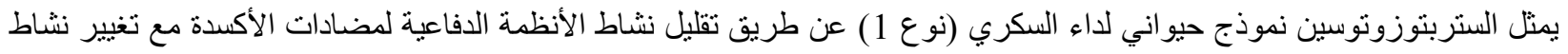
مضادات الأكسدة للإنزيمات مثل استخدام الثناي الأخضر و الكركم. لمردين

الهذف: عمل دراسات كيمبا حيوية, هستولوجية وليميانسيجية لدراسة تأثير الستربتوزوتوسين علي خلايا الكبد والبنكرياس . وقد استخدمت مضادات الأكسدة الطبيعية كطريقة حديثة لتحسين تأثير داء السكري علي الخلايا المصابة.

المواد والأسياليب: نم استحداث مرض السكري عن طريق الحقن البريتوني بجر عة واحدة من الستربتوزونوسين حديث التحضير ومذاب في505وسترات الصوديوم، والأس الهيدروجيني له يعادل 4,6 (الستربتوزوتوسين 45مجم/ كجم من وزن الجسم).

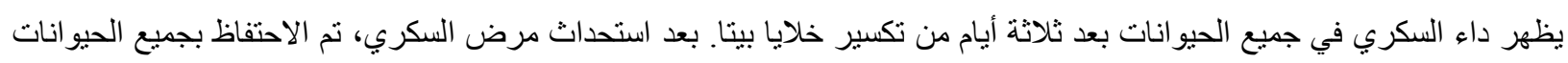
المصابة و السليمة في أقفاص منفصلين.

استخدم الثاي الأخضر و الكركم كمضادات طبيعية للأكسدة لتحسين الاضطرابات والتغيرات التركيبية الناجمة من استخدام الستربتوزوتوسين. أجريت در اسات خلوية وكيميانسيجية على التغير ات الناتجة في أنسجة الكبد والبنكرياس. وقد نم حساب ومقارنة وزن الجسم ومسنويات السكر في الدم والإنسولين. للاراسة المجهرية لخلايا الكبد و البنكرياس المصابة بداء السكري، نم أخذ عينات من الأنسجة المصابة و المعالجة وتم فحصها باثولوجيا.

النتائج: تناولت هذه الدراسة التحسن الناتج في كل من خلايا الكبد و البنكرياس عقب الإصابة الناجمة من استخدام الستربتوزوتوسين نتيجة استخدام الثابي الأخضر أو الكركم بجر عات معينة. ويمكن أيضا ملاحظة أن هذا التأثير يعتمد علي الوقت. تم تأكيد هذه النتائج بالكثف الهستوكيميائي للجليكوجين و الحمض النووي باستخدام صبغة بير أيودك شيف, وتفاعل فولجين.

الخلاصة: الكركم و الثاي الأخضر لهما تأثير قوي علي الخلايا المصابة بداء السكري في كبد وبنكرياس الجرذان. ويعتمد هذا التأثير الجيد علي الوقت. 